\section{Micropropagation of Three Pyrus Rootstocks}

\author{
Dennis Y. Yeo ${ }^{1}$ \\ Department of Horticulture, Oregon State University, Corvallis, OR 97331
}

Barbara M. Reed ${ }^{2}$

U.S. Department of Agriculture, Agricultural Research Service, National Clonal Germplasm Repository, 33447 Peoria Road, Corvallis, OR 97333-2521

Additional index words. acclimatization, auxin inhibition, explant initiation, shoot multiplication, pear, rooting

\begin{abstract}
Explants of three rootstock selections Pyrus calleryana Dcne 'Oregon Pear Rootstock (OPR) 157', P. betulifolia Bunge 'OPR 260', and $P$. communis L. 'Old Home' $x$ 'Farmingdale 230' ('OH x F 230') were initiated from forced branches of field-grown trees. 'OPR 260' and ' $O H \times$ X 230' shoots cultured on Cheng medium with IBA proliferated better than those on NAA. NAA and IBA at concentrations $>0.5 \mu_{\mathrm{M}}$ inhibited shoot multiplication. Overall, the best micropropagation medium for ' $O P R$ 260' and ' $O H \times F$ 230' was Cheng medium with $8 \mu_{\mathrm{M}} \mathrm{BA}$ and $0.5 \mu_{\mathrm{M}}$ IBA. Shoot multiplication of 'OPR 157' was best on $8 \mu_{\mathrm{M}} \mathrm{BA}$ and better on low NAA $\left(0.5 \mu_{\mathrm{M}}\right)$ or no auxin than on IBA. ' $O H \times$ F 230 ' rooted easily $(>80 \%)$ with all IBA and NAA treatments. The best rooting treatment (42.9\%) for 'OPR 260' was $10 \mu_{\mathrm{M}}$ IBA in darkness for 1 week; for 'OPR 157' (23.9\%), it was a 15-second dip in $10 \mathrm{~mm}$ NAA. Only rooted plantlets survived 4 weeks of greenhouse acclimatization. Chemical names used: $\mathrm{N}^{6}$-benzyladenine (BA); indole-3-butyric acid (IBA); napthaleneacetic acid (NAA).
\end{abstract}

Rootstocks are used to control or improve the growth of pear trees. They may impart precocity and dwarfing, influence fruit yield and quality, improve insect and disease resistance, and aid adaptation to wet or calcareous soils (Brooks, 1984; Westwood and Lombard, 1977). Evaluation of many pear genotypes as rootstocks with resistance to pear decline resulted in selection of clones Pyrus betulifolia, $P$. calleryana, and $P$. communis (Westwood et al.,1963). Several of these rootstocks were selected further by Melvin N. Westwood at Oregon State Univ., Corvallis, for their adaptability to Oregon conditions. 'Old Home' $\mathrm{x}$ 'Farmingdale 230' ('OH x F 230') ( $P$. communis) is a semidwarf rootstock, 'Oregon Pear Rootstock (OPR) 157' (P. calleryana) is semivigorous, and 'OPR 260' (P. betulifolia) is vigorous. Although vigorous, $P$. betulifolia rootstocks produce high fruit yield, perform well in clay and poorly drained soils (Lombard and Westwood, 1987), and are resistant to pear decline and fire blight (Brooks, 1984). Pyrus communis rootstocks are winter hardy and

Received for publication 21 Oct. 1994. Accepted for publication 10 Mar. 1995. Part of a thesis submitted by D.Y.Y. in partial fulfillment of the requirements for the MS degree. The use of trade names in this publication does not imply endorsement by the U.S. Dept. of Agriculture or Oregon State Univ. The cost of publishing this paper was defrayed in part by the payment of page charges. Under postal regulations, this paper therefore must be hereby marked advertisement solely to indicate this fact.

${ }^{1}$ Current address: 4-26-3 Futawa-Nishi, FunabashiShi, Chiba 274, Japan.

${ }^{2}$ To whom reprint requests should be addressed. adaptable to the northern United States; $P$. calleryana and $P$. betulifolia are more suited to warmer climates such as California and southern Oregon. All three selections are graftcompatible with many pear cultivars and with Cydonia oblonga L. (quince). Propagation of these genotypes has not been easy and, therefore, has limited their availability.

Tissue culture methods are available for many pear species and cultivars (Berardi et al., 1993; Cheng, 1978; Dolcet-Sanjuan et al., 1990; Nicolodi and Pieber, 1989; Singha, 1980; Stimart and Harbage, 1989). Differences exist among the various genotypes for both basal medium and growth regulators. Our objectives were to evaluate Cheng and woody plant media (WPM) containing a range of BA, NAA, and IBA concentrations as potential media for shoot multiplication of 'OPR 157', 'OPR 260', and ' $\mathrm{OH} \times \mathrm{F} 230$ '. Following shoot multiplication, four in vitro and one ex vitro rooting treatment were tested. Shoots from rooting treatment were evaluated further for their ability to acclimate to greenhouse conditions.

\section{Materials and Methods}

Stock cultures were grown on Cheng medium (Cheng, 1978). Growth-medium tests used Cheng medium and WPM (Lloyd and McCown, 1981). All media were adjusted to pH 5.2 with $\mathrm{KOH} / \mathrm{H}_{2} \mathrm{PO}_{4}$ before adding $3 \mathrm{~g}$ agar (Bitek, Difco, Detroit) and $1.25 \mathrm{~g}$ Gelrite (Schweitzerhall, South Plainfield, N.J.)/liter and autoclaving at $121 \mathrm{C}$ for $20 \mathrm{~min}$. Standard growth room conditions were a 16-h photoperiod supplied by cool-white (Watt Miser, GeneralElectric, Fairfield, Conn.) fluorescent bulbs $\left(25 \mu \mathrm{mol} \cdot \mathrm{s}^{-1} \cdot \mathrm{m}^{-2}\right)$ at $25 \mathrm{C}$.
Ecodormant branches were collected in February at the National Clonal Germplasm Repository (NCGR) at Corvallis, Ore., from mature 10- to 13-year-old, field-grown trees of 'OPR 157' (NCGR accession no. 1844), 'OPR 260' (NCGR no. 1379), and 'OH x F 230' (NCGR no. 1360) for forcing budbreak in the greenhouse. Shoots were pruned to 30 to $60 \mathrm{~cm}$, washed in $40 \mathrm{C}$ water with detergent, rinsed under running tap water for $30 \mathrm{~min}$, and placed in containers with $9 \mathrm{~g}$ Floralife (Floralife, Burr Ridge, Ill.)/liter in 30C water. Each week, 1 to $2 \mathrm{~cm}$ of the basal end of the branches were trimmed and the solutions were replaced. Leafy shoots were collected after 3 to 4 weeks in the greenhouse. A second set of explants was collected directly from fieldgrown trees in April.

Shoots $(2$ to $3 \mathrm{~cm}$ ) were stripped of leaves, washed in soapy water and rinsed under running tap water for $5 \mathrm{~min}$. Explants were disinfected in $10 \%$ commercial bleach (sodium hypochlorite $5.25 \%$ ) with five drops of Tween $20 / 500 \mathrm{ml}$, shaken on a rotary shaker for 10 min, and rinsed 3 times in sterile deionized water. Single-node sections were transferred to $20 \times 100$-mm tubes with $10 \mathrm{ml}$ of Cheng medium supplemented with $4.4 \mu \mathrm{MBA}$ (Sigma, St. Louis). Uncontaminated explants were transferred into Magenta GA7 (Magenta, Chicago) boxes with $40 \mathrm{ml}$ of the same medium and subcultured at 3-week intervals.

Media tested were Cheng and WPM with factorial combinations of BA at $0,2,4,8$, and $13 \mu \mathrm{M}$ and NAA or IBA at $0,0.5,1.0,2.0$, and $4.0 \mu \mathrm{M}$. The experiment was a three-factor (BA concentration, auxin concentration, and auxin type), randomized, complete-block design, with three blocks per treatment and five shoots per block (Magenta box) (total of 15 shoots). The total treatment period was 6 weeks with one transfer in the third week. Shoot proliferation was scored based on the number of usable shoots that were $\geq 1 \mathrm{~cm}$ long. Optimal shoot multiplication was based on plant appearance (greener leaves and minimal chlorosis), mean shoot height $>1.2 \mathrm{~cm}$, and proliferation rate. Factorial analysis and means separation were performed on data using MSTATC (Michigan State Univ.). Significance was recorded at $P \leq 0.05$.

Rooting treatments included either an auxin dip before planting in Cheng's medium without growth regulators or planting directly into a medium with $10 \mu \mathrm{M}$ NAA or IBA. Treatments included 1) a quick-dip treatment (15 sec) with $10 \mathrm{~mm}$ NAA or IBA dissolved in dimethyl sulfoxide. 2) Microcuttings were grown in medium with $10 \mu \mathrm{M}$ IBA in light or darkness for 1 week, then transferred to growthregulator-free medium under standard growth room conditions. 3) Control microcuttings were placed directly into growth-regulator-free medium. The experiment was a two-factor (treatment $\times$ genotype), randomized, complete-block design consisting of three blocks per treatment with five shoots per block (Magenta box) repeated once ( 30 shoots total). The root length, callus size, number of roots per shoot, and percent rooting were measured. To test ex vitro rooting, the shoot base $(2 \mathrm{~cm}$ height $)$ was 
dipped into a 1 Dip'N Grow (1\% IBA, $0.5 \%$ NAA, and $98.5 \%$ inert materials; AstoriaPacific, Clackamas, Ore.) : 1 water (v/v) solution, then planted directly into $200-\mathrm{ml}$ pots filled with a peat-perlite mix. The treated shoots were placed under intermittent mist (32-sec mist per 64-sec interval) on an enclosed bench for 2 weeks, followed by another 2 weeks in the greenhouse (16C night/27C day). Treatment consisted of 15 shoots per genotype, and the experiment was repeated once $(\mathrm{n}=30)$. The root length, callus size, number of roots per shoot, and percent rooting were measured after 4 weeks. All rooted and nonrooted shoots from the in vitro treatments were rinsed under tap water to remove adhering medium before transplanting to $800-\mathrm{ml}$ pot bands filled with 1 peat : 1 perlite $(\mathrm{v} / \mathrm{v})$ mix. The shoots were placed in a mist bed for 2 weeks, then transferred to the greenhouse bench for another 2 weeks as for ex vitro rooting.

\section{Results and Discussion}

More than $90 \%$ of the explants obtained from forced ecodormant branches were free of fungal or bacterial contamination, and $>90 \%$ produced shoots. Explants derived from shoots collected in April from the field were discarded because of contamination or browning. Pyrus calleryana 'OPR 157' and $P$. betulifolia 'OPR 260' were difficult to establish in culture due to either heavy callusing of the basal end and leaf axils or browning of medium and explants, but these symptoms declined after six to seven subcultures.

Optimal multiplication in a micropropagation system is based on high multiplication rates, an overall healthy appearance, and enough height for easy transfer. Shoot elongation after establishment was good $(\geq 1.2 \mathrm{~cm}$ after 3 weeks) at all auxin concentrations at $\leq 8$ $\mu \mathrm{M}$ BA (data not shown).

Pyrus betulifolia. Shoot multiplication for $P$. betulifolia 'OPR 260' on Cheng medium was influenced by BA concentration and auxin type and concentration (Table 1). Interactions were not significant $(P \leq 0.05)$ (Table 2$)$. Proliferation increased as BA levels increased with either auxin. At $13 \mu \mathrm{M}$ BA, many small shoots $(<1 \mathrm{~cm}$ long) were induced, but these are not included in the means. Of the treatments, 0 to $1.0 \mu \mathrm{M}$ IBA or NAA produced the best shoot multiplication at all BA levels. Explants did not multiply on medium without BA. More new shoots were produced on explants cultured on medium with IBA than with NAA. Shoot multiplication was significantly lower with auxin concentrations of 2 and $4 \mu \mathrm{m}$ than at 0 and $0.5 \mu \mathrm{M}$. With either medium the best shoot multiplication was obtained on 8 or $13 \mu \mathrm{M}$ BA with 0.5 or $1.0 \mu \mathrm{M}$ NAA (data not shown for WPM). Over all auxin levels, shoots grown on WPM produced more shoots than those on Cheng medium (mean 1.2 vs. 0.8), but without auxin, the media were equivalent. NAA at 2 and $4 \mu \mathrm{M}$ inhibited shoot multiplication compared to 0 and $0.5 \mu \mathrm{M}$. Other studies with pear have used only BA and no auxin for multiplication of $P$. betulifolia (Dolcet-Sanjuan et al., 1990; Nicolodi and Pieber, 1989). Based on shoot proliferation and overall appearance, including leaf size and color and shoot height, the best micropropagation medium for $P$. betulifolia 'OPR 260' was Cheng medium with $8 \mu \mathrm{M}$ BA and $0.5 \mu \mathrm{M}$ IBA.

Table 1. Means of shoot multiplication of Pyrus calleryana Oregon Pear Rootstock(OPR) 157, P. betulifolia OPR 260, and P. communis Old Home x Farmingdale 230 ('OH x F 230') on Cheng medium with BA and NAA or IBA.

\begin{tabular}{|c|c|c|c|c|c|c|c|}
\hline \multirow{3}{*}{\multicolumn{2}{|c|}{$\begin{array}{c}\text { Growth } \\
\text { regulator } \\
(\mu \mathrm{M}) \\
\end{array}$}} & \multicolumn{6}{|c|}{ Shoots per explant (no.) } \\
\hline & & \multicolumn{6}{|c|}{ Pear cultivar } \\
\hline & & \multicolumn{2}{|c|}{ OPR 260} & \multicolumn{2}{|c|}{$\mathrm{OH} \times \mathrm{F} 230$} & \multicolumn{2}{|c|}{ OPR 157} \\
\hline $\mathrm{BA}^{\mathrm{z}}$ & Auxin & NAA & IBA & NAA & IBA & NAA & IBA \\
\hline \multirow[t]{5}{*}{2} & 0 & $0.4 \pm 0.4^{y}$ & $0.9 \pm 0.3$ & $0.7 \pm 0.5$ & $0.6 \pm 0.5$ & $1.1 \pm 0.5$ & $0.2 \pm 0.3$ \\
\hline & 0.5 & $0.5 \pm 0.5$ & $1.1 \pm 0.4$ & $1.1 \pm 0.6$ & $0.7 \pm 0.5$ & $1.8 \pm 0.6$ & $0.2 \pm 0.3$ \\
\hline & 1.0 & $0.2 \pm 0.3$ & $0.5 \pm 0.2$ & $1.0 \pm 0.6$ & $0.5 \pm 0.5$ & $0.9 \pm 0.5$ & $0.2 \pm 0.3$ \\
\hline & 2.0 & $0.1 \pm 0.3$ & $0.5 \pm 0.3$ & $1.0 \pm 0.4$ & $0.5 \pm 0.5$ & $1.3 \pm 0.5$ & $0.1 \pm 0.3$ \\
\hline & 4.0 & $0.1 \pm 0.2$ & $0.8 \pm 0.4$ & $1.1 \pm 0.6$ & $0.5 \pm 0.4$ & $1.5 \pm 0.5$ & $0.0 \pm 0.0$ \\
\hline \multirow[t]{5}{*}{4} & 0 & $0.9 \pm 0.5$ & $1.2 \pm 0.4$ & $2.0 \pm 0.6$ & $1.2 \pm 0.5$ & $1.7 \pm 0.6$ & $1.1 \pm 0.5$ \\
\hline & 0.5 & $0.7 \pm 0.3$ & $1.8 \pm 0.5$ & $2.4 \pm 0.6$ & $1.1 \pm 0.5$ & $2.1 \pm 0.6$ & $1.1 \pm 0.5$ \\
\hline & 1.0 & $0.4 \pm 0.4$ & $1.5 \pm 0.5$ & $2.1 \pm 0.7$ & $1.0 \pm 0.6$ & $1.7 \pm 0.5$ & $1.0 \pm 0.4$ \\
\hline & 2.0 & $0.2 \pm 0$ & $1.3 \pm 0.6$ & $2.4 \pm 0.9$ & $0.9 \pm 0.6$ & $1.5 \pm 0.5$ & $1.0 \pm 0.5$ \\
\hline & 4.0 & $0.1 \pm 0.2$ & $1.3 \pm 0.6$ & $1.2 \pm 0.6$ & $0.7 \pm 0.4$ & $1.8 \pm 0.6$ & $1.4 \pm 0.6$ \\
\hline \multirow[t]{5}{*}{8} & 0 & $1.3 \pm 0.6$ & $1.7 \pm 0.5$ & $3.8 \pm 0.8$ & $3.0 \pm 0.7$ & $3.1 \pm 0.6$ & $2.5 \pm 0.6$ \\
\hline & 0.5 & $2.0 \pm 0.3$ & $2.6 \pm 0.5$ & $5.7 \pm 0.9$ & $6.9 \pm 0.8$ & $3.0 \pm 0.6$ & $1.9 \pm 0.6$ \\
\hline & 1.0 & $1.1 \pm 0.4$ & $2.4 \pm 0.5$ & $3.3 \pm 0.7$ & $4.1 \pm 0.7$ & $2.5 \pm 0.6$ & $1.6 \pm 0.6$ \\
\hline & 2.0 & $0.9 \pm 0.5$ & $1.9 \pm 0.6$ & $3.3 \pm 0.8$ & $2.3 \pm 0.8$ & $1.8 \pm 0.5$ & $1.9 \pm 0.6$ \\
\hline & 4.0 & $0.3 \pm 0.4$ & $2.1 \pm 0.6$ & $2.2 \pm 0.7$ & $1.5 \pm 0.6$ & $2.4 \pm 0.6$ & $1.5 \pm 0.6$ \\
\hline \multirow[t]{5}{*}{13} & 0 & $1.7 \pm 0.5$ & $2.0 \pm 0.3$ & $4.6 \pm 0.6$ & $4.1 \pm 0.6$ & $2.0 \pm 0.6$ & $1.5 \pm 0.5$ \\
\hline & 0.5 & $1.9 \pm 0.4$ & $3.3 \pm 0.6$ & $6.6 \pm 0.9$ & $8.7 \pm 0.8$ & $2.3 \pm 0.6$ & $1.1 \pm 0.5$ \\
\hline & 1.0 & $1.9 \pm 0.6$ & $2.7 \pm 0.3$ & $4.4 \pm 0.5$ & $5.3 \pm 0.7$ & $2.2 \pm 0.6$ & $1.2 \pm 0.5$ \\
\hline & 2.0 & $1.2 \pm 0.3$ & $1.8 \pm 0.5$ & $4.1 \pm 0.8$ & $3.3 \pm 0.8$ & $1.3 \pm 0.5$ & $1.1 \pm 0.6$ \\
\hline & 4.0 & $0.7 \pm 0.3$ & $2.4 \pm 0.8$ & $2.1 \pm 0.7$ & $2.3 \pm 0.6$ & $1.9 \pm 0.6$ & $1.0 \pm 0.5$ \\
\hline
\end{tabular}

${ }^{2}$ No multiplication at $0 \mu \mathrm{m} \mathrm{BA}$

${ }^{\mathrm{y}}$ Means \pm SE.

Table 2. Analysis of variance for means of shoot multiplication on Cheng medium.

\begin{tabular}{lccr}
\hline \hline & \multicolumn{3}{c}{ F value } \\
\cline { 2 - 4 } Source & OPR 260 & OH $\times$ F 230 & OPR 157 \\
\hline Auxin concentration (concn) & $4.9^{* *}$ & $73.6^{* * * *}$ & $11.7^{* * *}$ \\
BA concn & $26.6^{* * *}$ & $293.4^{* * *}$ & $161.0^{* * *}$ \\
Auxin $\times$ BA concn & $0.5^{\text {ss }}$ & $19.0^{* * * *}$ & $3.8^{* * *}$ \\
Auxin type & $45.2^{* * *}$ & $8.8^{* *}$ & $283.1^{* * *}$ \\
Auxin concn $\times$ auxin type & $1.4^{\text {ss }}$ & $5.5^{* *}$ & $6.9^{* *}$ \\
BA concn $\times$ auxin type & $1.0^{\text {ss }}$ & $8.6^{* *}$ & $67^{* *}$ \\
Auxin $\times$ BA $\times$ auxin type & $0.4^{\text {ss }}$ & $2.6^{* *}$ & $1.8^{\text {ss }}$ \\
\hline
\end{tabular}

Auxin $\times$ BA $\times$ auxin type

01 or 0.001 , respectively.

Table 3. Means of growth characteristics of Pyrus calleryana 'Oregon Pear Rootstock (OPR) 157', $P$. betulifolia 'OPR 260', and P. communis 'Old Home' x 'Farmingdale 230' ('OH x F 230') on Cheng medium with four rooting treatments.

\begin{tabular}{|c|c|c|c|c|c|c|c|}
\hline \multirow[b]{2}{*}{ Genotypes } & \multicolumn{3}{|c|}{ Treatment } & \multirow{2}{*}{$\begin{array}{c}\text { Shoots rooting } \\
\text { or acclimatized } \\
(\%)\end{array}$} & \multirow{2}{*}{$\begin{array}{c}\text { Roots } \\
\text { (no.) }\end{array}$} & \multirow{2}{*}{$\begin{array}{l}\text { Callus } \\
(\mathrm{cm})\end{array}$} & \multirow{2}{*}{$\begin{array}{l}\text { Shoot } \\
\text { length } \\
(\mathrm{cm})\end{array}$} \\
\hline & Auxin & Concn & Method $^{2}$ & & & & \\
\hline \multicolumn{8}{|l|}{ P. betulifolia } \\
\hline \multirow[t]{4}{*}{ OPR 260} & NAA & $10 \mathrm{~mm}$ & Dip & $19.8 b^{y}$ & $0.2 \mathrm{~b}$ & $0.2 \mathrm{a}$ & $0.2 \mathrm{~b}$ \\
\hline & IBA & $10 \mathrm{~mm}$ & Dip & $17.5 \mathrm{~b}$ & $0.3 \mathrm{~b}$ & $0.3 \mathrm{a}$ & $0.2 \mathrm{~b}$ \\
\hline & IBA & $10 \mu \mathrm{M}$ & Dark & $42.8 \mathrm{a}$ & $1.0 \mathrm{a}$ & $0.2 \mathrm{a}$ & $1.2 \mathrm{a}$ \\
\hline & IBA & $10 \mu \mathrm{M}$ & Light & $27.9 \mathrm{ab}$ & $0.5 \mathrm{ab}$ & $0.2 \mathrm{a}$ & $0.5 \mathrm{~b}$ \\
\hline \multicolumn{8}{|l|}{ P. communis } \\
\hline \multirow[t]{4}{*}{$\mathrm{OH} \times \mathrm{F} 230$} & NAA & $10 \mathrm{~mm}$ & Dip & $85.6 \mathrm{ab}$ & $8.4 \mathrm{a}$ & $0.6 \mathrm{~b}$ & $2.0 \mathrm{a}$ \\
\hline & IBA & $10 \mathrm{~mm}$ & Dip & $81.1 \mathrm{~b}$ & $6.9 \mathrm{ab}$ & $0.9 \mathrm{a}$ & $1.4 \mathrm{a}$ \\
\hline & IBA & $10 \mu_{\mathrm{M}}$ & Dark & $90.0 \mathrm{a}$ & $5.8 \mathrm{bc}$ & $0.5 \mathrm{~b}$ & $1.4 \mathrm{a}$ \\
\hline & IBA & $10 \mu \mathrm{M}$ & Light & $85.6 \mathrm{ab}$ & $4.2 c$ & $0.6 \mathrm{~b}$ & $2.1 \mathrm{a}$ \\
\hline \multicolumn{8}{|l|}{ P. calleryana } \\
\hline \multirow[t]{4}{*}{ OPR 157} & NAA & $10 \mathrm{~mm}$ & Dip & $23.9 \mathrm{a}$ & $0.3 \mathrm{a}$ & $0.3 \mathrm{a}$ & $0.1 \mathrm{a}$ \\
\hline & IBA & $10 \mathrm{~mm}$ & Dip & $21.9 \mathrm{a}$ & $0.2 \mathrm{a}$ & $0.3 \mathrm{a}$ & $0.1 \mathrm{a}$ \\
\hline & IBA & $10 \mu \mathrm{M}$ & Dark & $15.0 \mathrm{a}$ & $0.2 \mathrm{a}$ & $0.2 \mathrm{~b}$ & $0.1 \mathrm{a}$ \\
\hline & IBA & $10 \mu \mathrm{M}$ & Light & $13.3 \mathrm{a}$ & $0.1 \mathrm{a}$ & $0.3 \mathrm{a}$ & $0.2 \mathrm{a}$ \\
\hline
\end{tabular}

${ }^{2}$ Dipped for $15 \mathrm{sec}$ in auxin and grown with $16 \mathrm{~h}$ light for 3 weeks or grown for 1 week on medium with auxin either in darkness or $16 \mathrm{~h}$ light, then transferred to hormone-free medium in the light for 2 weeks.

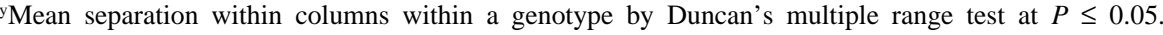
Microcuttings not treated with auxin did not form roots or callus and did not acclimatize. 
and Pieber, 1989) was reported for P. betulifolia cultivars.

Pyrus communis. The BA concentration $x$ auxin concentration $\times$ type interaction was significant in the shoot multiplication of ' $\mathrm{OH}$ X F 230', but multiplication was mainly influenced by $\mathrm{BA} \times$ auxin concentration, the $\mathrm{BA} \times$ auxin concentration interaction, and to a lesser extent auxin type (Table 2). The highest shoot multiplication was obtained with 8 and $13 \mu \mathrm{m}$ BA with $0.5 \mu \mathrm{M}$ auxin. Mean shoot proliferation was greater for plants grown on medium with NAA (2.8 shoots), rather than with IBA (2.5 shoots). The best multiplication was on $0.5 \mu \mathrm{M}$ IBA (8.7 shoots). Both NAA and IBA at $0.5 \mu \mathrm{M}$ improved shoot multiplication; higher concentrations were inhibitory. BA and NAA concentrations and medium type also influenced multiplication (data not shown for $\mathrm{WPM})$. The $\mathrm{BA} \times \mathrm{NAA}$ concentrations interaction was significant, with the best multiplication at $0.5 \mu \mathrm{M}$ NAA with 8 and $13 \mu \mathrm{M}$ BA. The BA level $\times$ medium interaction was significant, with 8 and $13 \mu \mathrm{M}$ BA producing the most shoots on Cheng medium. NAA at $>0.5$ $\mu \mathrm{M}$ inhibited shoot multiplication on both media. Cheng is a modified MS medium (Murashige and Skoog, 1962), and MS or modified MS with BA concentrations of 3.3 to $20 \mu \mathrm{M}$ produced successful multiplication of $P$. communis (Dolcet-Sanjuan et al., 1990; Lane, 1979). Our results indicated that ' $\mathrm{OH} x$ F 230' shoots grown on $0.5 \mu \mathrm{M}$ NAA or IBA produced the best shoot proliferation and 2 and $4 \mu \mathrm{M}$ auxin inhibited multiplication. To our knowledge, there are no reports of IBA effects on $P$. communis multiplication. Some researchers tested NAA at concentrations $<0.5 \mu \mathrm{M}$ and found no beneficial effects (Lane, 1979; Singha, 1980); others omitted auxin altogether (DolcetSanjuan et al., 1990). Lane (1979) found that NAA $(0.05 \mu \mathrm{M})$ and gibberellic acid $(1 \mu \mathrm{M})$ were slightly inhibitory to shoot proliferation in 'Bartlett'. Based on shoot proliferation and overall appearance, the best micropropagation regime in this study for $P$. communis ' $\mathrm{OH} \times \mathrm{F}$ 230 ' was on Cheng medium with $8 \mu \mathrm{M}$ BA and $0.5 \mu \mathrm{M}$ IBA. Although shoot count was highest at $13 \mu \mathrm{M}$, the shoot height and appearance were best at $8 \mu \mathrm{M}$.

' $\mathrm{OH}$ x F 230' had the highest percentage (>80\%) of rooting of the three genotypes, and it rooted well on all media (Table 3 ). Although $10 \mu \mathrm{M}$ IBA in darkness led to $90 \%$ rooted shoots, the number of roots per shoot were significantly fewer than with the 10-mM NAA dip. NAA stimulated rooting of $P$. communis cultivars at $8 \mu \mathrm{M}$ (Viseur, 1987) and $10 \mu \mathrm{M}$ (Lane, 1979; Singha, 1980). Other investigators have had success rooting $P$. communis cultivars with IBA at $1 \mu \mathrm{M}$ (Lane, 1979) and 10 or $32 \mu \mathrm{M}$ (Dolcet-Sanjuan et al., 1990). Lane (1979) found that $10 \mu \mathrm{M}$ NAA produced $70 \%$ more rooted shoots than $10 \mu \mathrm{M}$ IBA, which was considered toxic for 'Bartlett'. The largest callus for ' $\mathrm{OH}$ x F 230' shoots was induced with a $10-\mathrm{mm}$ IBA dip $(0.9 \mathrm{~cm})$, and it was larger than all other calli. More rooting occurred in ' $\mathrm{OH} \times \mathrm{F} 230$ ' shoots, which had the largest mean callus size in all treatments than in all the others. Calli induced by the $10-\mathrm{mm}$
IBA and NAA dips developed mainly around the point of root origin. More roots were produced per ' $\mathrm{OH} \times \mathrm{F} 230$ ' shoot with the 10mM NAA and IBA dips than with other combinations, but root lengths were similar in all.

Pyrus calleryana. The greatest influences on shoot multiplication for $P$. calleryana 'OPR 157 ' were the BA concentration $\times$ auxin type and auxin concentration $\times$ auxin type (Table 2 ) interactions. Shoot multiplication was best at $8 \mu \mathrm{M}$ BA without IBA or with 0 or $0.5 \mu \mathrm{M}$ NAA. Overall, Cheng medium with 0 or 0.5 $\mu \mathrm{M}$ NAA produced the most shoot proliferation; higher auxin levels were inhibitory. Shoot multiplication was highest at $8 \mu \mathrm{M}$ BA and declined at $13 \mu \mathrm{M}$, mainly due to the production of many shoots $<1 \mathrm{~cm}$ high. Optimum BA concentrations for various $P$. calleryana genotypes have varied from 0.5 to $20 \mu \mathrm{M}$ (Table 1 ) (Berardi et al., 1993; Dolcet-Sanjuan et al., 1990; Stimart and Harbage, 1989). Stimart and Harbage (1989) reported that $5 \mu \mathrm{M}$ IBA reduced the multiplicative effects of $\mathrm{BA}$, but lower concentrations did not affect $P$. calleryana 'Bradford'. A similar inhibitory effect on multiplication occurred at concentrations $>0.5 \mu \mathrm{MNAA}$ with 'OPR 157'. Berardi et al. (1993) reported that NAA at $0,0.05$, and $0.1 \mathrm{mg}^{-1 i t e \mathrm{r}^{-1}}(0,0.025$, and $0.05 \mu \mathrm{M})$ did not affect shoot proliferation of $P$. calleryana seedlings. These concentrations were well below the optimal $0.5 \mu \mathrm{M}$ NAA for 'OPR 157'. Over all growth regulator combinations, shoots grown on Cheng medium multiplied significantly better than those on WPM, but at $0.5 \mu \mathrm{M}$ $\mathrm{NAA}$ and $8 \mu \mathrm{M} \mathrm{BA}$, the multiplication rates were equal (data not shown for WPM).

'OPR 157' shoots rooted poorly in all media with the highest percentage rooting (23.9\%) obtained with the 10-mm NAA dip treatment (Table 3 ). The controls grown on basal medium did not root. Berardi et al. (1991) reported $2.5 \mu \mathrm{M}$ NAA $\left(0.5 \mathrm{mg} \cdot\right.$ liter $\left.^{-1}\right)$ promoted rooting significantly better than 2.5 $\mu$ M IBA $\left(0.5 \mathrm{mg} \cdot\right.$ liter $\left.^{-1}\right)$ for $P$. calleryana seedlings cultured on half-strength MS for 6 weeks. Dolcet-Sanjuan et al. (1990) induced high percentages of rooting of $P$. calleryana ' $\mathrm{OPR}$ 191 ' with a 15 -sec dip in $10 \mathrm{~mm}$ IBA or by growing the shoots on medium with 10 or 32 $\mu \mathrm{M}$ IBA for 7 days followed by transfer to medium with no growth regulators. Stimart and Harbage (1989) were unable to induce rooting of 'Bradford' with $\operatorname{IBA}(0,4.92,14.8$, and $39.8 \mathrm{~mm}$ ). Although we were able to induce rooting with NAA and IBA, the percentages were low. The number of roots per shoot and root length were low in all treatments. Comparison of these results with earlier data indicate a large amount of variation among genotypes of $P$. calleryana.

Ex vitro rooting treatment. Neither rooting nor survival occurred in any cultivar for the ex vitro rooting treatment (Dip'N Grow) and subsequent acclimatization. We were interested in testing this technique because successful ex vitro rooting can save time and reduce costs, but to our knowledge, ex vitro rooting has not been reported for pear.

Acclimatization. All in vitro-rooted shoots survived after 4 weeks of acclimatization in the greenhouse (Table 3). The best rooting treatments resulted in $\leq 90 \%$ of micropropagated shoots rooting and subsequently developing into plants in the greenhouse. Shoots that did not root in vitro died during acclimatization. Rooting and survival were absent for the control shoots (not rooted) or those that did not root in vitro.

\section{Summary}

Micropropagation systems for the three pear rootstocks were similar but not identical. Axillary buds of forced ecodormant branches of all genotypes initiated well on Cheng medium supplemented with $4.4 \mu_{\mathrm{M}}$ BA. Cheng's medium with $8 \mu \mathrm{M}$ BA was the best for multiplication of all three genotypes, but auxin types varied. IBA and NAA concentrations $>0.5$ or $1 \mu \mathrm{M}$ inhibited the shoot multiplication in all three genotypes. For $P$. betulifolia 'OPR 260 ', the best shoot multiplication required $0.5 \mu \mathrm{M}$ IBA, and rooting was best on medium with $10 \mu \mathrm{M}$ IBA (in darkness) for 1 week. Multiplication for $P$. communis ' $\mathrm{OH}$ x F 230' was best on medium with $0.5 \mu \mathrm{M}$ IBA and rooting with the 10-mM NAA or IBA dip treatments. Micropropagation for P. calleryana 'OPR 157' was good on Cheng or WPM with $8 \mu \mathrm{M}$ BA and $0.5 \mu \mathrm{M}$ NAA with the $10-\mathrm{mm}$ NAA dip treatment for rooting. Acclimatization of rooted plantlets was successful with 2 weeks each in the mist bed and 2 weeks in the greenhouse. We believe this to be the first report of a comprehensive study of auxin in pear micropropagation media. Our results showing stimulatory effects of low concentrations and inhibitory effects of high concentrations indicate the importance of auxin concentration for pear micropropagation.

\section{Literature Cited}

Berardi, G., R. Infante, and D. Neri. 1993. Micropropagation of Pyrus calleryana $\mathrm{Dcn}$. from seedlings. Scientia Hort. 53:157-165.

Berardi, G., D. Neri, A. Majorino, and R. Adversi. 1991. In vitro rooting of Pyrus calleryana. Acta Hort. 300:181-188.

Brooks, L.A. 1984. History of Old Home $x$ Farmingdale pear rootstocks. Fruit Var. J. 38(3):126-128.

Cheng, T-Y. 1978. Clonal propagation of woody plant species through tissue culture techniques. Proc. Intl. Plant Prop. Soc. 28:139-155.

Dolcet-Sanjuan, R., D.W.S. Mok, and M.C. Mok. 1990. Micropropagation of Pyrus and Cydonia and their responses to Fe-limiting conditions. Plant Cell Tissue Organ Cult. 21:191-199.

Lane, W.D. 1979. Regeneration of pear plants from shoot meristem-tips. Plant Sci. Lett.16:337-342.

Lloyd, G. and B. McCown. 1981. Commerciallyfeasible micropropagation of mountain laurel, Kalmia latifolia, by use of shoot tip culture. Proc. Intl. Plant Prop. Soc. 30:421-427.

Lombard, P.B. and M.N. Westwood. 1987. Pear rootstocks, p. 145-183. In: R.C. Rom and R.F. Carlson (eds.). Rootstocks for fruit crops. Wiley, New York.

Murashige, T. and F. Skoog. 1962. A revised medium for rapid growth and bioassays with tobacco tissue cultures. Physiol. Plant. 15:473497. 
Nicolodi, R. and K. Pieber. 1989. Versuche zur mirovegetativvermehrung von Pyrus betulifolia. Mitt. Klosterneuburg 39(6):247-250.

Singha, S. 1980. In vitro propagation of 'Seckel' pear, p. 59-63. In: R. Zimmerman (ed.). Proceedings of the conference on nursery production of fruit plants through tissue culture: Applications and feasibility. Agricultural Res. Re- sults. vol. 11. U.S. Dept. of Agriculture, Science Education Administration, Beltsville, Md.

Stimart, D.P. and J.F. Harbage. 1989. In vitro shoot proliferation of Pyrus calleryana from vegetative buds. HortScience 24:298-299.

Viseur, J. 1987. Micropropagation of pear, Pyrus communis L., in a double phase culture medium. Acta Hort. 212:117-124.
Westwood, M.N. and P.B. Lombard. 1977. Pear rootstock and Pyrus research in Oregon. Acta Hort. 69:117-121.

Westwood, M.N., F.C. Reimer, and V.L. Quackenbush. 1963. Long term yield as related to ultimate tree size of three pear varieties grown on rootstocks of five Pyrus species. Proc. Amer. Soc. Hort. Sci. 82:103-108. 